\title{
THE ROLE OF SOCIAL MEDIA IN CONTEMPORARY DEMOCRACY: A COMPARATIVE STUDY OF APC AND PDP CAMPAIGNS DURING THE 2015 AND 2019 GENERAL ELECTIONS IN NIGERIA
}

\author{
Chukwu Solomon Ugochukwu (Corresponding author) \\ Institute of Graduate Studies Istanbul Aydin University \\ Beşyol, İnönü Cd. No:38, 34295 Küçükçekmece/İstanbul, Turkey \\ Email: solomonugochukwuchukwu@stu.aydin.edu.tr
}

Tel: +90 5350744615

\begin{abstract}
The study focuses on the use of social media in the 2015/2019 general elections in Nigeria. The study focuses on how the PDP (Peoples Democratic Party) and APC (All Progressive Congress) made use of social media in political mobilization, political communication and spreading information in the two general elections. In the course of the study, several literatures and researches about the elections and use of social media in Nigeria were studied to get different perspectives of how the political parties made use of several social media platforms in their political campaigns. Based on the study it was found out that both parties made use of twitter more than any other platform for political mobilization, communication and campaign. The use of party sponsored hashtags was prevalent in the political process while social media influencers were majorly used by party officials. False propagandas shared by both political parties were prevalent in the political process using social media as the appropriate tool. Social media was also used by supporters of both parties, civil societies, electorates and the electoral commission to monitor the electoral processes in the different polling areas.
\end{abstract}

Keywords: Social media, general election, Twitter, democracy, communication, political mobilization.

DOI: $10.7176 / \mathrm{NMMC} / 96-09$

Publication date:July $31^{\text {st }} 2021$

\section{Introduction}

Since the evolution of the 17th century, the use of election has become one of the most important activities in a democratic government. The same case is seen in Nigeria. Nigeria joined the League of Nations who are practicing democracy in 1979 which saw Alhaji Shehu Shagari become the first democratically elected president of the country 1979 but was soon overthrown by military dictatorship in 1983. Democracy finally came back in 1999 and Nigeria has gone ahead to practice democracy for 20 years (1999-2019) and conducting elections at every four years intervals. Elections have become useful, costly and as well as posing various degrees of problems to such an extent that one needs to study on how these problems would have been averted and the determining alternatives tools that would have reduced these costs.

In modern societies, election has been generally referred as an essential element for realization of representative government and democracy. It has been seen as one of the effective means to effective representation in governmental offices or positions Nosiri (2018). Katz cited in Hague \& Harrop (2010) election as the defining institution of modern democracy. Elections are very central to the development or growth and consolidation of democracy in any state.

The success of any political candidates or political parties in election is determined by the strategies they adopted in electioneering campaign in order to win the support of the majority of the voters. Through the media, the people's voice and their perception on any political issues are resonated. According to Chinedu-Okeke and Obi (2016) "argued that the media is an important element in a society and even in a democracy. It is an apparatus which is used to pass information, teach and mobilize. It is an important tool which also act as a bridge between the electorate and the government. The functions of the media include increase in the growth of the society, increase in developmental strides, making democracy better and helps in achieving good governance.

Social media has also been employed in mobilizing politically, used in electioneering campaigns and the overall sourcing for votes has become a constant trend among politicians and public office seekers (Okoro and Santas, 2017). According to McQuail (2005, cited in Suntai \& Targema, 2017, p. 198) "social media has been reported by different researchers as a new way through which political parties and politicians can mobilize support 
without meeting face to face with the electorate and also get grass-root support." In Nigeria, the President Goodluck Jonathan made use of the social media as a tool for political campaign where he made announcement of this intention to run for the 2011 presidential election through the party's Facebook page. This made his political campaign to take on unprecedented momentum among the youth and which play a significant role to President Goodluck Jonathan's success (Olarode, 2014). The 2011 was the first time social media were adopted in electioneering campaign in Nigeria (Okoro \& Santas, 2017).

In Nigeria, social media was employed by many political parties and people who were vying to be voted for to mobilize and gain acceptance (Suntao \& Targema, 2017, p.199). Oseni (2015, cited in Suntai \& Targema, 2017, p.199) posited that from the period of election campaign to the time of voting, gathering of results and final announcement of victors by the commission in-charge of the electoral process, social media was employed in the dissemination of information to the electorate. Social media has become an important apparatus used by political parties, electoral commission, civil societies and other electoral stakeholders because of its participating and interacting nature. Social media is now used for political engagement and all round political activities (ChineduOkeke \& Obi, 2016).

In the 2015 and 2019 general election, the two leading political parties known as All Progressive Congress (APC) and People's Democratic Party (PDP) made use of several tools of social media for effective electioneering campaign with the purpose to achieve political communication, mobilization and support towards gaining political power. Therefore, this Research work is set to critically study the role of social media in contemporary democracy by making a comparative study of use of social media by APC and PDP for campaigns during the 2015 and 2019 general elections in Nigeria.

\section{Literature review \\ 2.1 Social Media}

Social media has become the best invention in the mobile technological era. It has helped in improving communication, marketing, advertising, reaching out and more especially, based on our study, elections and democracy. The broadness of social media has evolved into various aspects and perspectives. Shahjahan and Christy (2014) opined that social media has taken the process of using words for communicating into new and advanced levels, transforming companies, increasing and creating various means of societal communication and creating participatory advertising and marketing. The back and forth nature of social media which brings interaction have been employed by organizations, political parties, businesses, governmental establishments to interact with a unlimited number of customers, respondents and electorates online.

Apuke and Tunca (2018) opined that social media eases communication between individuals and organizations. It gives permission to users to create web-based profile. The authors also opined that the application of social media is being employed in advertising, public relations, strategic and political communication. Social media is a new way of communicating which focuses on social networking, help users to express themselves, a portal for information sharing, interactions, freedom of thoughts and give them the ability to express their own views in the internet (Apuke and Tunca, 2018). Social media is termed social because if the interactive and collaborative nature of the tools which are employed in the various platforms.

Based on the definition of Divya and Bulomine (2014) social media is a technological innovation which is webased. It increases interaction between users, increase face-to-face communication which is done online and the technological is powered by the internet. Rautela and Singha (2017) opined that the technology uses a web 2.0 innovation that gives permission to users to create contact and share content. The authors further implied that social media promotes communication and also implements the other functions of traditional mode of advertising. It helps organization to talk and communicate with their customers. Hajli (2013) wrote that social media creates a portal where information is shared and interactions carried out without any form of physical meeting. It helps users to generate their own content. Organizations use the platform to talk about new ideas, new product development and also initiate/make sales. Michael (2015) reiterated that social media can also be called a read-write web which gives power to users to move beyond passive viewing of the published content but also contributing to the published content. The author further wrote that the media is seen as a tool for knowledge building through communication and exchange of information. 


\subsubsection{Forms of social media}

Social network - Social network are social media which are used in building relationships, connection, helps in building brands and are use in business developments. They are also employed in market study and research and building relationships. Facebook is the major example of a social network. Others include Google + and LinkedIn.

Microblogging - Microblogs are employed in creating business based connections. Ravuela and Singhal (2017) opined that this form of social media allows user to stay in tuned to content of other users and replies are seen publicly. Major examples include Twitter and Tumblr.

Blogging or social publishing sites - In this form of social media, users are not limited to the numbers of characters in a post or update. They are used by individual or organizations to inform users about products and other things with details. Ravuela and Singhal (2017) opined that they are used to publish content online. Example of this social media include WordPress and Blogger.

Media sharing networks - These social media platforms are used to share different forms of media online. The media include pictures, video files, live videos and other multi-media documents. The platform is used to create awareness, used in the generation of user generated content (UGC) and most organizations use these platforms to engage with their followers and customers. Ravuela and Singhal (2014) wrote that these platforms are perfect advertising and marketing platforms and they can be used in reaching so many people at the same time. Major examples of media sharing social media include YouTube, Instagram, Flickr and Snapchat.

Interest based network - The social media occupies a small niche in the social media space. The platform helps users with same interest to connect with themselves. This form of social media brings people together into the same space and help them share and relate with themselves. Major examples of the social media include Goodreads and Soundcloud. The social media can be used for brand awareness, gain customer loyalty and also help in customer engagement. For example, Goodreads is meant for readers, book lovers and writers while Soundcloud is specific for music lovers, practices and other music enthusiast.

Discussion forums - This social media is used for discussion, news sharing, source of information based on certain topics and it is used in giving opinions. Discussion forums are also used for market survey and research about a market niche. The platform is also used in the advertisement and promotion of products. This social media platform includes Reddit, Digg and Quora (Ravuela and Singhal, 2017).

Bookmarking sites - Bookmarking sites are used to share contents and also discuss new happenings on social media. It can also be used to promote brands and also drive traffic to different websites. This social media platform is good for social media marketing and improve customer loyalty. Major examples of this form of social media include Flipboard and Pinterest. Kaplan and Haenlien (2010) further opine that the new media can include other forms like collaborative projects, virtual games and virtual social media.

\subsubsection{Imbedded Social media tools which fosters communication}

It should be fully noted that the relevant social media tools or forms are often used for the mass mobilization of any society especially in a country which has fully and effectively integrated the use of social media in dealing with certain challenges facing the socio-economic development of Nigeria. Spurgeon (2008) wrote that there are two key points which allows social media channels to be a veritable tool in fostering social development communication. The key points are;
i. Personalization
ii. Participation
i. Personalization

Social media is personalized because based on several algorithms which are employed by the programmers, content are programmed or tailored to individual needs. Unlike the other conventional media forms, social media provides a personalized form of engagement between information/content providers and social media users. Social media users are always keen and want social media brands, organizations, political parties and general content creators to interact with them on a personal level and to be treated as individuals. Online digital marketers and content creators online have been seen to be use well-tailored content which are personalized to bring about participation with social media users and allows carried out campaign which are targeted to the right audience. Michael (2015) opine that personalization of social media campaigns by content creator and social media marketers have been consistently used by organizations to selectively target the right audience. Personalization of content has been proven to make brands look more authentic in the eyes of consumer which leads to the feeling that they have a person-to-person relationship with the brand. This personalization is not just a motive used by business brands alone, political organization, non-governmental organization and online policy enforcers have also incorporated and started using personalized content to boost participation and to predict social media user behavior.

Fan and Poole (2006) further wrote that personalization is related to customization, adaptation, one-to-one relationship and individualization. The main aim in personalization is customer loyalty or as the case in electoral 
practices, electorate loyalty. Building a one-to-one relationship which is focused on knowing the need of each individual and also help to satisfy a goal which addresses each individual needs. Personalization is mainly focused on creating relevant or targeted web experiences for individual user of the social media platform. It is focused on bringing enhanced social interactions in social media. Jenkins (2006) wrote that personalization makes a system or social media to become more relevant to users. It brings about custom made interface, peculiar access to information and content and also bring about peculiarity.

\section{ii. Participation}

In an easy to understand definition, participation in social media is the situation whereby there is partnership between content creators and social media users develop and contribute content in meaningful ways. Villi and Malikainem (2016) opine that participation in social media can be seen from various perspectives. They opine that participation involves and point towards human collaboration. Carpentier (2011) opine that participation is a political and ideological concept which is linked to political power. The author further wrote that participation is different from interaction. Interaction can be considered to be an aspect of participation which cannot be equated to participation. In various contrary opinions, other authors view participation as less political and less preoccupied with the notion of power. Villi and Malikainem (2016) opine that participation differ from older media form which focuses on spectatorship and consumption. Jenkins (2006) wrote that participation bridge the gap of having just producers and consumers to having interactions and collaborations. Participation focuses more on acting together, communicating with each other and less of power struggle and politics.

In social media, interaction is of the essence and it turns audiences into participants who are active and are termed users (Jenkins, 2006). In participation, audience becomes users. Villi and Malikaniem (2016) wrote that audience only captures one segment of the new form of media experience. The term "users" focuses on "doing" which include sharing, posting, chatting, uploading, commenting and tweeting. Audiences which are focused in the old form of communication are often fixed ad seen as passive audience while users of the new or contemporary / participatory media are seen as hyperactive and co-creators (Jenkins, 2006).

\subsection{The concept of elections and democracy 2.2.1 Democracy}

Jongh (2017) wrote that the word democracy derived its meaning from ancient Greek and it means "rule by the people". The ancient Athenians created the concept of elections as a reactionary measure to fight against authoritarian system of government. Mesfin (2008) defined democracy as a type of government which gives sole powers to the people to determine who governs them. It makes the society and people the major determining factors in determining their political and social fate. It is a system which encourages ordinary people to take charge of their political fate. It gives people the power of self-determination. Dalton et al (2007) stated eight criteria involved in defining democracy and they include voting right to everyone, the opportunity to be voted for, the right for those in power politically to compete for elected position, the process of electing politically representative should be free and fair, freedom to associate with anyone, political party and social groups, freedom to express opinions, source of information should not be from one source and institutions which depends on votes and other expressions of preference. Democracy is dependent on democratic institutions and the various activities which is seen in a democratic government. It is also stated that if an electoral process directs the workings of a government, the government is democracy. Dalton et al (2007) further wrote that citizens identify democracy with the institutions and processes of democratic governance. The key elements in defining democracy are free and fair elections, responsive government, multiparty competition and popular control/majority rule. Wotjasik (2013) wrote that democracy includes emphasis on freedom and liberty as its essential goals. The goals will be achieved with the effective utilization of the various institutions of democracy. The author citing Franklin, D Roosevelt's articulation of the four democratic freedom, he listed political liberties, participation rights of citizens, equal justice before the law and equal right for women as four of the core democratic values.

The protection of individual liberty and rights by the rule of law is an essential aspect of democracy. Osinakachukwu and Jawan (2011) citing Schumpeter, wrote that democracy means people have the opportunity of accepting or refusing men who are given to them. The authors further define democracy as conducting elections and choosing leaders that will represent the majority. Rousseau and Rivero (2003) define it as the power of the people as it manifests in ways of thinking, behaving and organizing. It enhances participation and help majority to have influence over the everyday decisions affecting their lives. Democracy brings about the ascension of the most popular candidates who are chosen via fair and honest elections that are carried out periodically. The process promotes the political participation of all the adult citizens. A full participation of the 
people during electioneering campaigns gives the government that wins a legitimate foundation to govern.

\subsubsection{Elections}

Election is the founding pillar of any democracy. It is seen as the most important means by which citizens can either vote for a leader or remove another leader and it is a costly affair. Michael (2015) wrote that election is usually brought about when people collectively choose a candidate through voting. Through voting, the candidate with the highest vote gets elected. Elections are primarily about the choice of people. The derivation of the word election is from the Latin word "eligere" which means "pick out, to choose". Johnson (1999) opine that election constitute the major process of instituting government and for holding public officials accountable. It is a mainstay of any good and democratic government. Osinakachukwu and Jawan (2011) wrote that election facilitates and shapes democracy. It is the political will of the citizen to decide who should govern. It is through election the expression of the people is shown through legitimacy and leadership succession.

The process is a way of censuring, reposing function in a ruler that is popularly accepted and ejecting an unpopular leader. In as much there is no rigging during the election, the process shuns mutiny and chaos in a system. Mesfin (2008) argued that election is the principal instrument which compels or encourage the makers of policy to pay adequate attention to its citizenry. The winning political party which becomes the ruling party holds the mandate of the people temporarily which is dependent on the tenure of leadership. Wojtasik (2013) gave several key features of election in a democratic system and they are as follows;

i. There should always be uncertainty of the electoral outcome. The uncertainty is dependent on the decision of the votes.

ii. Possibility of alternating of power and provision of a de facto division into those in power and the opposition

iii. Citizens are empowered to whom and to what extent they will grant legitimacy to exercise power on their behalf and also when a change in power should occur.

iv. Any decision which is legally made during the election is irrevocable and cannot be changed in any other way than through the next election

v. The opposition after the conduct of an election has the mandate to control the ruling party and also present alternative solutions to those proposed by the ruling government.

vi. There is mutual influence of the citizens and those in power, as well as elites and the masses to ensure a thorough election.

For election to be held, the need for political parties is key. Mesfin (2008) argue that election require the existence of a multiparty system so that citizens make decision by voting for the competing candidates fielded by various political parties holding views which are different. For a healthy democracy, the existence of opposition parties is critical to put the ruling party in check at all times. Johnson (1999) wrote that the opposition parties point out defective policies and provide their alternatives hoping that voters will entrust them with their mandate in the next election.

\section{Element of election}

For an election to be adequate, free and fair and be able to consolidate a democratic process in a country, some elements of election must be put in place. Odinakachukwu and jawan (2011) enumerated several elements of election. A well-defined, competent, relative independent and non-partisan electoral body which is responsible for the conduct of elections, the existence of an impartial judiciary for the interpretation of electoral laws and also responsible for the adjudication on electoral matters, a mass media devoid of influence from the politicians, a police force that will help supervise the conduct of elections and electoral laws should be available to guide the conduct of the election, organization of political parties, voter's registration, nomination of candidates for elective public office and declaration of election result.

\section{Functions of the election}

Elections are put in place in a democratic government to achieve some political, social and developmental functions. Wojtasik (2013) analyzed the functions into seven types and they include;

i. Delegation of political representation - This function allows electorate to vote for those individuals who they think is the best representation based on different factors which are evident. The result of election transfer power from a group of people to the elected person to make political decision. The election of political representation increases the speed and accuracy in making decision, 
presumption that those who are elected are more competent in making accurate decisions and give importance to decision made and to increase the social impact of the decision.

ii. Selection of the political elite - This function has a two stage character. The first results from the existence of political parties as entities which lead to the institutionalization of the political sphere. The second focus on the role of the electorate. The institutionalization of political parties allows political parties to be veritable ingredients in the political system. They help in the selection process of credible representation with the appropriate characteristics which will help in the election proper. The role of political parties in selection of political elites shows that they help in guiding the decision making of voters and guide their choice. The second function focuses on the role of the electorate in the election and the manifestation of their personal preference despite the personality or political affiliation.

iii. Legitimization of those in power - The legitimization of those in power and the consequence they bring is the basic function of election. The resultant transfer of the decision making to representatives, legitimize the political system. Democratic election is a legitimate procedure of takeover of power, giving to the politicians exercising power the comfort of having a social mandate which helps in consolidating democracy

iv. Control over authorities - This function happens in two dimensions. The negative aspect is when as a result of the elections the mandate of the governing is revoke. It is positive when the ruling through elections, renew their mandate to govern to the next term. Election divides politicians into winners and losers or those who will exercise political powers and the opposition. Through election, the power of control is on the voters. A voting majority might choose to withdraw support for a politician and declare for the opposition

v. Ensuring political accountability - The function assume the possibility of drawing consequences against persons holding public office. It consists in the expression of disapproval of their political activity and the consequences which include political consequences too. The enforcement of political accountability is expressed through elections, as a result of which the previously granted power to an office holder is either upheld or revokes.

vi. Creation of political programmes - The creation of political programmes gives ability to parties to carry out their programmes function. Political parties go about this through translation of general principles and values represented by the parties into postulate of specific political action. The use of public dissemination of the programme in order to gain on its basis new members and supporters and also generate electoral support.

vii. Recreation of the image of public opinion - Election serves as a mechanism of translating public preference into legitimization of power and also by the opportunity of actively engaging citizens in the processes of electing authorities and systemic channeling of their actively in this field.

\subsection{The role of social media in elections \\ 2.3.1 Social media and political campaigns}

Kumar and Natarayan (2016) opine that commercial campaigns pr marketing focuses on promoting an idea, products, service just to increase profit levels and increase their market shares. The same can be said about political campaigns. Political campaigns focus on promoting a political party, candidates, agendas, targeting specific voters, increase awareness which all focuses on a political party or candidate winning an election. Political campaign is simply an organized effort which seeks to influence the decision making process towards a political party or political candidate. Owen (2014) opines that it is often called electoral campaign where representatives are chosen via elections. In political campaign, communication of the appropriate message is important. Campaign actions include commercial advertising, recruiting volunteers and social propaganda. Media campaign is gradually transitioning from broadcast model associated with traditional media to new media platforms which is mostly made up of the internet and social media. Due to the immerse growth and reach of social media, politicians and political parties have learned to reach the public on a personal and social level using social media. Owen (2014) opine that politicians use social media for communication on a larger scale with minimum effort being employed.

Apuke and Tunca (2018) also wrote that social media has become a channel politicians use to propagate diverse campaign message to their constituents who have interest in their campaigns. With social media platforms like Facebook and Twitter, political aspirants appeal to citizens, contact supporters and those supporters use the participatory nature of social media to contribute on various agendas and also mobilize. 


\subsubsection{Social media and political communication}

Communication is an essential aspect in politics, election and democracy. Political communication is essential for information dissemination and storage of information. The introduction and use of social media in political discourse and communication has brought another paradigm to the idea of political communication. The place of political dialogue and participation comes into play. Ayo et al (2015) define political communication as an aspect of political science and communication which deals with the production, dissemination, procession and effects of information, within a political context. It further includes media studies, speech analysis made by politicians and those who are keen in influencing the political process. The term also involves formal and informal conversations among members of the public (Stefan and Linh, 2012).

Steffan and Linh (2012) argued that social media such as SNS (social networking sites), microblogging sites, weblogs has been use to play increasingly important role in shaping political communication and discourse. They are used to enable the growth of political participation, political activism and democracy at large. Social media has become an additional instrument which has been employed to create dialogs between the electorate, the elected and those who are vying for political posts. The 2008/2012 United States of America elections and the 2015 Nigeria presidential elections show how social media is becoming an increasing tool in aiding political communication (Ayo et al, 2015).

\subsubsection{Social media and political mobilization}

As the word implies, mobilization is the entire process involved in inducing people to participate in a movement, politics, influence policies and carry out change. Michael (2015) opined that it is a process by which parties, activists or groups use to bring other people to participate in their ideology. Participation can only happen after mobilization is achieved. Jensen (2017) opined that political mobilization focuses on initiating people or inciting people into a desired political action by focusing on their greatest political needs and expectations. Akindele (2004) wrote that political mobilization means the process of bringing people together emotionally and making them internalize communality of societal values, attitudes and orientation in achieving particularistic and specified objectives. Marc et al (2010) implied that political mobilization is an important precondition for most forms of political participation and engagement. Participants have to be informed and recruited before they can participate. Mobilization or party agent now use social media to reach out to potential participants. Michael (2015) further wrote that political leaders contact citizens through their social media accounts. Social media based mobilization is now a well-accepted way to increase awareness and collective action.

Dungse et al (2018) in their study compared level of mobilization from online social networks with mobilization from face-to-face contact. The findings show that social media mobilization increase the attendance in offline political campaigns and increase the diversity of the members involved. Rossini et al (2018) opine that internet based mobilization significantly increases civic and political interest. The use of microblogging social media like Twitter has been found to be effective in mobilization including other online social networks. In mobilization, social media helps to reach political supporters who are harder to contact through the use of traditional media. It helps to increase the interest of the public in political campaigns. Amandha (2014) gave five structures which helps in political mobilization. These structures involve communication, organization, mobilization, validation and scope enlargement Social media has replaced the old form and structures used in mobilizing. Social media platforms are embedded with all the five structures involved in political mobilization.

\subsection{Theoretical framework}

Five theories will be explained in this study in relation with social media use and acceptance in election. The theories will be used to explain the use and adoption of social media for various purposes. The models include media dependency theory (MDT) and technology acceptance model (TAM)

\subsubsection{Media dependency theory (MDT)}

The theory was proposed by Melvin Defleur and Sandra Ball-Rokeach in 1976 with a common assertion which implied that the basis of a media influence resides in the relationship between the larger social system, the media's role in the system and how the audience or the users relate with the media (Michael, 2015). The theory states that, the more dependent an individual is on the media for having his or her needs fulfilled, the more important the media will be to that person (Ha et al, 2013). The theory explores the audience's use of various media platforms and the way they alter some mass communication processes to satisfy their information and 
communication need. The authors define dependency as a relationship in which the capacity of individuals to attain their goals is contingent upon the information resources of the media system. Media dependency model offers a path to explore user dependency in regards to an array of media systems which are available. Halpern (1993) opine that individual media dependency which is a micro-level of the media dependency model accesses an individual's dependency relations with regard to a specific media.

Michael (2015) opine that considering the impact social media has affected the day to day routine of the world, social networks like Facebook and Twitter have become part of the way people communicate, socialize, spend time and create awareness. Social media has taken precedence over other communication platforms because of its accessibility and usability. Dependency on social media for provision of necessary information and interaction has become greater. Based on the theory which is summarized in, "the more a person depends on having need gratified by media use, the more important the media's role will be in the person's life and furthermore, the more influence the media will have". The more the public relies on social media platforms like Facebook and Twitter for communication, mobilization, activism, participation and daily routines, the more value and influence social media has (Annie, 2011).

\subsubsection{Technology acceptance model (TAM)}

Technology acceptance model is an information system theory which was developed to explain computer usage and the acceptance of information technology. The theory was developed by David, Bagozzi and Warshaw in 1989 to replace Fishbein and Ajzen's theory of reasoned action (TRA) which opine that the behavioral intention of people depends on the person's attitude and subjective norms (Rupak et al, 2013). While TRA was theorized to explain the general human behavior, TAM was propounded to explain the determinant off computer acceptance which are general and capable of explaining user behavior across a broad range of end user computing technologies and the user population (Ma and Liu, 2005). Michael (2015) opine that the basic postulation of TAM is that the use of any media system or technology is determined by the behavioral intention which is determined by the person's attitude towards the use of the system and also by the perception of its utility. TAM is hinged on two measures which are perceived ease of use (PEOU) and perceived usefulness (PU). Perceived usefulness is the degree at which a person believes that the use of a system will improve his performance. Perceived ease of use refers to the degree at which a person believes that the use of a system will be effortless.

Michael (2015) combined media dependent theory and technology acceptance model to explain the choice and use of some interactive social media platforms in various elections and political processes. The constant use of some of the social media platforms which are involving, open ended, and interactive to mobilize, seek participation en mass and engagement in the election proper focuses on the media dependent theory. While the optimum use of these platforms are justified by their perceived usefulness and ease of use.

\section{Analysis and result: Elections in Nigeria and social media use}

\subsection{Study methodology}

The study made use of secondary data collected from the Independent National Electoral Commission database, social media handles of various news outlets, journals, articles, websites and other secondary means of data collection. The study made use of literature review study design. A literature review study design is a qualitative research method which focuses on analysing several studies which have been carried out in related studies and draw conclusions based on the results of the studies.

\subsection{Overview of politics in Nigeria}

Nigeria is a multi-ethnic and multi-religious state. Politically, Nigeria is differentiated into six geo-political zones which include North Central, North East, North West, South South, South East and South West. The geopolitical zones divide the country into different fragments which are characterized with sameness in religious practice, similar culture, similar language and most importantly, sameness in political affiliation and partisanship. Alao et al (2013) wrote that the country is the largest black nation on the planet and studies shows that there is always a Nigeria in the midst of five black people. Nigeria has a population of almost 200 million people with an estimated population of half a billion in 20 year's time due to its geometric increase in population growth. Multi-ethnicity and multi-religious practice are the two predominant factors which contribute on how the country operates politically and during elections. 
Ojukwu et al (2019) wrote that election in Nigeria is characterized by acrimony, nepotism, bitterness, killing and political manipulation. Obakhedo (2011) wrote that the Nigeria electoral and political scene has been overshadowed by corruption in the electoral process, abuse of power and wrong usage of power of incumbency and government which has been unaccountable.

Table 1: Past and present political leaders in Nigeria

\begin{tabular}{|c|c|c|}
\hline Name & Terms/ Reigns & Office \\
\hline Nnamdi Azikiwe & 1963-1966 & President \\
\hline Yakubu Gowon & 1966-1975 & Military ruler \\
\hline Muritala Mohammed & 1975-1976 & Military ruler \\
\hline Olusegun Obasanjo & 1976-1979 & Military ruler \\
\hline Shehu Shagari & 1979-1983 & Civilian President \\
\hline Mohammed Buhari & 1983-1985 & Military ruler \\
\hline Ibrahaim Babagida & $1985-1993$ & Military ruler \\
\hline Ernest Shonekan & 1993-1993 & Civilian President \\
\hline Sani Abacha & 1993-1998 & Military ruler \\
\hline Abdulsalami Abubakar & 1998-1999 & Military ruler \\
\hline Olusegun Obasanjo & 1999-2007 & Civilian President \\
\hline Umaru Musa Yar'Adua & $2007-2010$ & Civilian President \\
\hline Goodluck Jonathan & $2010-2015$ & Civilian President \\
\hline Mohammed Buhari & 2015-till date & Civilian President \\
\hline
\end{tabular}

Source: Author (2021)

Table 1 enumerated the past and present presidents of Nigeria since 1960 - till date. The first president was Nnamdi Azikiwe and the present president is Mohammed Buhari from 2015 - till date.

Social media was first used in the Nigeria election campaigning in the 2011 general election. It was the pivotal point in using the new media in the electoral process in Nigeria. Apuke and Tunca (2018) wrote the overwhelming use of social media was instigated by the use of the new media in the 2008 United State of America presidential elections where Barack Obama used web-based social networking system especially Facebook, Twitter and YouTube in his electioneering campaign. The first notable use of Facebook for politicking was done by the Obama campaign team. Social media use in Nigeria election is focused on four important stakeholders in the democracy of Nigeria. Plac (2012) cited the Independent National Electoral 
Commission (INEC), politicians and political parties, the electorate and civil societies. The use of social media by those groups was focused on achieving interrelated objectives.

\subsection{Social Media use in 2015 General Elections}

The 2015 general election in Nigeria came up on the backdrop of the success achieved by the People's Democratic Party's presidential candidate in the 2011 elections. The PDP also scored huge victories in the gubernatorial and National Assembly elections too. 'Orji (2015) wrote that prior to the election, there were concerns about the possibility of large scale election violence depending on the winner of the presidential election. The obvious peaceful nature of the election came as a big surprise considering the volatile political environment which was evident at that time. Thurston (2015) opined that the peaceful nature of the election was viewed as positive step in the right direction and towards the consolidation of Nigeria's democracy. The plan towards the success of the 2015 general election started with the INEC organized election voter's registration to get permanent voters card (PVC) for Nigerians without a voter's card to be eligible to vote (Olakunle and Modupe, 2015).

The two major political parties involved in the election was the People's Democratic Party's candidate with President Goodluck Jonathan as their presidential candidate and All Progressive Congress (APC). Presidential candidate was Mohammed Buhari. The APC was then a new party which was formed on February $6^{\text {th }}, 2013$ with the merger of four opposition political parties. Olakunle and Modupe (2015) wrote that election campaigns by the political parties involved in the election started their election campaigns in different states in Nigeria. Orji (2015) wrote that the electioneering campaigns by both political parties were targeted at smearing the integrity of the different candidates representing both parties. Thurston (2015) wrote that the APC's campaign was hinged on the idea that the PDP have been in power for years without securing any noticeable change in the country. They also focused on the security issues of Boko Haram which was ravaging the Northern part of Nigeria. Other striking points which was used by the opposition was the corruption in Nigeria and the mismanagement of the nation's wealth.

The election was meant to hold on February $14^{\text {th }}$ and $28^{\text {th }}\left(14^{\text {th }}\right.$ for Presidential and National Assembly election while $28^{\text {th }}$ was for Gubernatorial and State Houses Assembly election). INEC later postponed the elections based on security concerns raised by the National Security Council. The election was postponed to $28^{\text {th }}$ March for Presidential election and National Assembly elections while April $11^{\text {th }}$ for Gubernatorial and State Houses of Assembly elections (Orji, 2015).

\section{Presidential Election}

Mohammed Buhari of the All Progressive Congress emerged as the President elect. Thurston (2015) opine that it should be noted that it is the fourth time the candidate was contesting the presidential election after he contested in 2003. 2007 and 2011. Buhari defeated incumbent president Goodluck Jonathan with more than 2 million votes. The actual result was 15,424,921 votes for Buhari and 12,853,162 votes for Jonathan (Olakunle and Modupe, 2015). Orji (2015) wrote that the result of the 2015 election was significant because it was the first time an opposition party will upstage the incumbent government in Nigeria using legitimate means.

Table 2: 2015 Presidential election results

\begin{tabular}{|l|l|l|l|}
\hline No & Party & States won & Total Number of Votes \\
\hline 1 & APC & 21 & $15,424,921$ \\
\hline 2 & PDP & 15, FCT & $12,853,162$ \\
\hline
\end{tabular}

Source: INEC (2015) (2015 presidential election results retrieved $25^{\text {th }}$ July 2019 http://inecnigeria.org/newsall/2015-presidential-election-result/

Table 2 shows the presidential results of 2 political parties out of the 14 political parties who participated in the election. The APC won the election and also met the electoral requirement of getting $25 \%$ votes in 27 states out of the 36 states and the FCT. 
Olakunle and Modupe (2015) opine that the distribution of the result in the presidential election shows the level of how ethnicity and religion are important factors to consider in voting dynamics in Nigeria. The Muslim dominated North voted massively for Buhari while the Christian dominated South voted massively for Jonathan except the South Western part of Nigeria which had divided votes based on political affiliation.

\section{Social Media use}

The growth of social media and its used in the entire political process in the 2015 election increased in comparison with what was attained in the 2011 general election. Apuke and Tunca (2015) wrote that Facebook was employed by politicians and political parties because of its participatory nature. Facebook was used for campaigning, election crusade and voter's mobilization. Political aspirants used the platform to disseminate information and mobilization of voters. Alongside Facebook, Twitter was also a major platform which was employed by both political parties. Suntai and Targema (2015) wrote that Twitter was often employed by both political parties to influence electorate on who to vote and was also used for mobilization by Civil Society and the electoral commission. Civil societies used the platform for the broadcast of important information. Apuke and Tunca (2015) talked about the use of hashtags which influences Twitter hangouts. Popular hashtags which were employed by political parties, Civil Society and the electorates include \#MeetGej, \#FeBuhari, \#MarchoutJonathan, \#WhyIwillVoteGEJ, \#MarchForBuhariand \#GMB15. Others include \#LagosForYou, \#NigeriaDecides, \#Nigeria2015, \#iPlegdeToVote, \#MyPVCnow, \#GoVote and \#VoteNoFight

The hashtags were used for election monitoring by the commission and also to track the election contents which are dropped on social media by electorate. Voters and Civil Societies used the hashtags to share pictures, videos and other contents online (Oseni, 2015). Oseni (2015) opine that social media was employed by citizen journalist to share election results in the different polling units across different states in Nigeria. Oyenuga (2015) wrote that social media was used to give firsthand information of collated results and also increased political participation too. Suntai and Targema (2017) also wrote that social media was used as a watchdog, a platform used to encourage people to vote and a way which can be used to prevent the manipulation of already published results gotten firsthand. Udoka (2015) in his study opined that there is a positive relationship between the use of social media and how the electorate views a political candidate. In the 2015 election process, politicians used social media to give and share a positive aspect of themselves online and it helps attract supporters and subsequent voters to their course. Oyenuga (2015) in his research found out that since the new media (social media) is not well regulated, there was a high level of misinformation and misrepresentation in the 2015 elections. Apuke and Tunca (2015) wrote that the election was characterized by online characters assassination, violence, hate speech and abuse on social media. Apuke and Tunca (2015) implied that social media was intentionally used to increase the divide between the Northern and Southern part of Nigeria which was already volatile. The political atmosphere of the country prior to the election was full of hate, ethnic and religious divide. Though social media has it many positives, it was also used to intimidate, discredit and trigger online and offline conflicts between electorates.

\subsection{Social Media use in 2019 General Elections}

The 2019 general elections were proposed to be the freest, safest and fairest election after the successful nature of the 2015 elections. The INEC was now headed by Prof Mahmood Yakubu who was appointed in 2015 (Ojukwu et al, 2019). Ojukwu et al (2019) opine that the election was well planned based on reports by the electoral commission. Preparations for the elections started with the release of INEC strategic plan 2017-2021 which had three key operations which include election management system, election project plan and election operations support center. Sule (2019) opine that according to the electoral commission, there were 84 million registered voters and 72 million of the total voters had permanent voters card (PVC). There were 91 registered political parties with 119,973 polling units, 120 accredited domestic observers, 36 accredited foreign observers and 23,000 candidates competing for 1,558 positions. In February $27^{\text {th }}, 2019$, the result of the Presidential election was released and the incumbent President Mohammed Buhari won his re-election bid. He defeated the Presidential candidate of the People's Democratic Party by over 3 million votes. 
Table 3: 2019 Presidential election results

\begin{tabular}{|l|l|l|l|}
\hline No & Candidates & Political Parties & Result \\
\hline 1 & Buhari Mohammed & APC & $15,191,847$ \\
\hline 2 & Abubakar Atiku & PDP & $11,262,978$ \\
\hline
\end{tabular}

Source: INEC (2019) (2019 presidential election results. Retrieved on $25^{\text {th }}$ July,2019. http://www.inecnigeria.org/2019-presidential-election-results/

Table 3 shows that there were just two major political parties which were involved in the Presidential elections. Incumbent President Buhari Mohammed won with a total of 15,191,847 votes over PDP Presidential candidate who had $11,262,978$ votes.

Sule (2019) opined that mixed and opposite reports were reported after the Presidential election. At the extreme negative, there were claims of widespread fraud, ballot snatching, vote-trading and impersonation by the two major political parties. At the extreme positive, the African Union (AU) and the electoral commission said the election was peaceful and credible. Ojukwu et al (2019) wrote that many elections at different polling units were cancelled due to violence, over-voting and bypassing of the Smart Card Readers by electoral personnel. The gubernatorial elections in different states were held on March $9^{\text {th }}$ after one month of gruesome collation of all the results. The ruling party, APC, won a total of 15 gubernatorial seats while the lead opposition party, PDP, won 14 gubernatorial seats. The opposition won Oyo, Adamawa, Bauchi and Imo states from the ruling party while the ruling party took Gombe and Kwara states.

\section{Social media use}

Though many researchers have not been carried out on the impact of social media in the February/March 2019 general election in Nigeria, several articles have been written to highlight the importance of social media in the general election especially in political mobilization. Majority of the political campaigns carried out by the incumbent political party APC was targeted at discrediting the presidential candidate of the PDP. The use of influencers was prevalent prior to the election days. There were many publicized hashtags which were focused on telling internet users about the corruption charges which were unfounded against the presidential candidate of the PDP.

Otunji (2019) wrote that the APC also employed smear campaign using multiple APC handles on twitter to spread propaganda. The PDP was focused on discrediting the incumbent president who is also the presidential candidate of the APC. Like the APC, the PDP also focused on using paid influencers on social media for political mobilization and propaganda. Otunji (2019) opined that Twitter, Facebook and Instagram were the major platforms which were used by users in the elections. The use of political hashtag was a key factor which was adopted by social media users to spread news, election results, mobilize voters to come out and also improve political participation. Hashtags which were predominantly used in major platforms include \#2019Election, \#Nigeria2019, \#NigeriaDecides2019, \#Atikulated, \#TakeItBack, \#NextLevel, \#PMB4Plus4, \#Obi-diently, \#ElectionDay and \#AtikuIsWinning

Other hashtags were also sponsored by social media influencers to push an ideology and psychologically instigate people to vote for a certain candidate. Olatunji (2019) wrote that social media influencers were critical in influencing the decision making of users across various social media platforms. Many political parties and their various candidates leveraged the use of these influencers to get votes and increase user engagements in their posts. Based on the participatory nature of social media, many users became tools in the hands of politicians to represent the image of the candidate in a positive light. Politicians employed skilled social media users to act as their mouthpiece online and also control their different social media accounts. Adeagbo and Omodunbi (2019) wrote that Twitter was the stand out social media platform in terms of user engagement with the use of short videos, memes, gifs and info-graphics. Olatunji (2019) opine that the use of online polls by social media influencers, blogs and other users were used to determine the convictions of Nigerians towards the election and also find out their personal perception involving notable political candidates. Social media was used as a tool for 
mobilization by many political parties and social media influencers. There were several engagements on a daily basis on several key aspects of the election on social media. One of the prominent features in the electioneering process was the use of social media (twitter especially) so spread hate, smear the name of political opponents and spread propaganda. Olatunji (2019) wrote that the social media became a space where hate was publicized between the followers of the major political parties. Some political parties employed bloggers who deliberately incite the public and spread propagandas.

\section{Discussion, conclusion and recommendation}

The general objectives of this research is to investigate on the role of social media in contemporary democracy by making a comparative study of APC and PDP campaigns during the 2015 general elections in Nigeria. The study also revolves around how social media was incorporated and adapted the both elections in Nigeria. The use of social media in democratic processes has acted as a lubricating force in the process and also revolutionized political communication, campaigning and political participation, many research has also shown that social media has brought a certain level of negativity in the political campaign processes.

Social media was first used in the Nigeria election campaigning in the 2011 general election. It was the pivotal point in using the new media in the electoral process in Nigeria..

The 2015 general election in Nigeria came up on the backdrop of the success achieved by the People's Democratic Party's presidential candidate in the 2011 elections. The PDP also scored huge victories in the gubernatorial and National Assembly elections too. The election campaigns by the political parties involved in the election started in different states in Nigeria. Based on what was happening on social media, the two major political parties adopted negative campaign strategies, fierce personal attacks and negative promotion through social media. There were reports that showed that electioneering campaigns by both political parties where targeted at smearing the integrity of the different candidates representing both parties.

The APC campaign was hinged on the idea that the PDP have been in power for years without securing any noticeable change in the country. They also focused on the security issues of Boko Haram which was ravaging the Northern part of Nigeria. Other striking point which was used by the opposition was the corruption in Nigeria and the mismanagement of the nation's wealth. Facebook was employed by politicians and political parties. Facebook was used for campaigning, election crusade and voter's mobilization. Political aspirants used the platform to disseminate information and mobilization of voters. Alongside Facebook, Twitter was also a major platform which was employed. Twitter was often employed to influence electorate on who to vote and was also used for mobilization by Civil Society and the electoral commission.

Hashtags were used for election monitoring by the electoral commission to track the election contents which were dropped on social media by electorate. Voters and Civil Societies used the hashtags to share pictures, videos and other contents online. Social media was employed by citizen journalist to share election results in the different polling units across different states in Nigeria. Social media was used to give first-hand information of collated results and also increased political participation too. There was a high level of misinformation and misrepresentation in the 2015 elections because social media is not regulated. In the 2015 election, both parties used social media to intentionally increase the divide between the Northern and Southern part of Nigeria which was already volatile. The political atmosphere of the country prior to the election was full of hate, ethnic and religious divide. Though social media has it many positives, it was also used to intimidate, discredit and trigger online and offline conflicts between electorates.

In the 2019 elections, majority of the political campaigns carried out by the incumbent political party APC was targeted at discrediting the presidential candidate of the PDP. The use of influencers was prevalent prior to the election days. There were many publicized hashtags which were focused on telling internet users about the corruption charges which were unfounded against the presidential candidate of the PDP. The APC also employed smear campaign using multiple APC handles on twitter to spread propaganda. The PDP was focused on discrediting the incumbent president who is also the presidential candidate of the APC. Like the APC, the PDP also focused on using paid influencers on social media for political mobilization and propaganda. Social media was used as a tool for mobilization by both political parties and social media influencers. There were several engagements on a daily basis on several key aspects of the election on social media. One of the prominent features in the electioneering process was the use of social media (twitter especially) so spread hate, smear the name of political opponents and spread propaganda. Social media became a space where hate was publicized between the followers of the political parties. Some political parties employed bloggers who deliberately incite 
the public and spread propagandas. Further result of the study showed that both parties made use of twitter more than any other platform for political mobilization, communication and campaign. The use of party sponsored hashtags was prevalent in the political process while social media influencers were majorly used by party officials. False propagandas shared by both political parties were prevalent in the political process using social media as the appropriate tool. Social media was also used by supporters of both parties, civil societies, electorates and the electoral commission to monitor the electoral processes in the different polling areas.

More studies should focus on the use of social media as a tool for spreading false propaganda by political parties in the 2015 and 2019 national elections in Nigeria. Based on the research conducted in this study found out that, most of the articles, posts and comments attributed to the last two elections in Nigeria were focused on increased the divide in Nigeria and spreading hate among political followers.

\section{References}

Abdulahi, A (2013). Independent National Electoral Commission (INEC) and the conduct of 2011 election in Nigeria: A paradigm shift. International journal of politics and good governance, 4(4); pp 1-10

Adeagbo, A.A and Omodunbi, O.O (2019). Election gifting and the ordeal of democracy in Nigeria. European scientific journal, 45(5): pp 119-132

Alao, D. O, Alao, E. O and Nwogwugwu, N.N (2016). A critical appraisal of the management of 2011 general elections and implications for Nigeria's future democratic development. Kuwait chapter of Arabian Journal of business and management review,2(5); pp 109-122

Andreou, C.R (2018). Research on political information and social media key points and challenges for the future. El professional de la informacion, 27(5): 964-974

Apuke, O.D and Tunca, E.A (2018). Understanding the implication of social media usage in the electoral processes and campaigns in Nigeria, Global media journal, 16(31-149), pp: 1-8

Apuke, O.D and Iyendo, T.O (2017). The impact of internet usage on academic research and development Students perspective in a Nigerian University. Journal of humanities and social sciences: African scholar publication and research international, 6:228-248

Ayo, C., Jonathan, O., Moses, D and Nicholas, O (2015). Credible elections and the role of social media: The case of Nairaland in the 2014 Osun gubernatorial election. Covenant University Ota, Nigeria, 112

Bandipo, A. O. (2016). The role of the new media in the electioneering process of developing nations: A case study of Nigeria, 2015. M.Sc Thesis Faculty of Arts, University of Malta.

Biswas, A., Ingle, N. \& Roy, M. (2014). Influence of social media on voting behavior. Journal of Power, Politics and Governance, 2(2), 127-155.

Bud, D (2013). Hashtag politics: The polyphonic revolution of \#Twitter. Pepperdin journal of communication research, $1: 4 ; 16-22$

Burns, S amd Tran, G (2014). The effect of social media \& web development on product promotion. College liberal arts,

Carpentier, N (2011). Media and participation: A site of ideological - democratic struggle, Bristol,UK

Charles, A. Jonathan, O., Moses, D and Nicholas, O (2015). Credible elections and the role of social media: The case of Nairaland in the 2014 Osun Gubernatorial election. Covenant University, Ota, Nigeria.

Chinedu-Okeke, C. F. \& Obi, I. (2016). Social media as a political platform in Nigeria: A focus on electorates in South-Eastern Nigeria. IOSR Journal of Humanities and Social Science, 21(11), 6-22.

Dalton, R.J., Doh, C.S and Willy. J (2007). Popular conception of the meaning of democracy. Democratic understanding in unlikely places. Center for the study of democracy, University of California, Irvine. 
Divya, S and Bulomine, R (2014). An empirical study on effectiveness of social media as a marketing tool. International journal of current research and academia review, 2(3), 10-40

Dungse, Y., Mato, S., Makinde, $\mathbf{O}$ and Chidozie, F (2018). Social media, political mobilization and participatory policies in Nigeria. eGovernment for democratic consolidation and transformation, CUCEN2018, 53-66

Edegoh, L. O. N. \& Anunike, O. W. (2016). Voter's assessment of social media use for 2015 electioneering campaigns by the two leading political parties in Nigeria. African Research Review, 10(4), 1840.

Fan, H and Poole, M.S (2006). What is personalization? Perspectives on the design and implementation of personalization in information systems. Journal of organizational computing and electronic commerce, 16(3), 179-202

Gregory, D.S., Jerome, N.N., Chao, G and Richard, D.H (2015). \#AdvocatingForChange: The strategic use of hashtags in social media advocacy. Advances in social work,16(1),154-169

Gevertz, D and Greenwood, G (2010). Crafting and effective social media policy for healthcare employees. Health lawyer, 33(6), 28-33

Hague, R. \& Harrop, M. (2010). Comparative government and politics: An Introduction (8h ed). Hampshire: Palgrave Macmillan

Haplern, P (1993). Media dependency and political perceptions in an authoritarian political system: the case of Chile's left. University of Southern California

Jensen, M. J (2017). Social media and political campaigning: Changing terms of engagement. The international journal of press and politics, 22(1); 23-42

Johnson, H (2006). Convergence culture, New York: NYU press

Johnson, M (1999). Corruption and democratic consolidation. Prepared for a conference on democracy and corruption, Shellby Cullon Davis center for historical studies, Princeton University.

Jongh, I (2017). The prospects for democratic consolidation: A case study and comparison of Botswana and South Africa. Department of international relations, Stellenbosch University

Kaplan, A.M and Haenlein, M (2010). Users of the world unite! The challenges and opportunities of social media. Business Horizon, 53(1), 59-68

Kunar, K.A and Natarayan, S (2016). Role of social media in political campaigning and its evaluation methodology: A review. Sona global management review, 10(3): 1-12

Mesfin, B (2008). Democracy, elections and political parties: A conceptual overview with special emphasis on Africa. Institute for security studies, Paper 166, 1-11

Ma, Q and Liu, L.Y (2004). The technology acceptance model: A meta-analysis of empirical findings. Idea group publishing

Michael, O.P (2015). An evaluation of the effectiveness of social media as tools for political mobilization in Nigeria's 2015 presidential election. Department of mass communication, University of Nigeria, Nsukka

Lassen, D.S and Brown, A.R (2011). Twitter: The election connection? Social science comparative review, 29(4): 419-436

Momah, P.O (2015). Electoral commission and the conduct of elections in Nigeria: The role of INEC. Election and governance

Nosiri, U. D. (2018). Election and electoral system: A comparative analysis. In S. I. Ekwonna (Ed), Introduction to comparative politics and government: Readings in principles, structures, governance and case studies (pp. 337-353). Owerri: Ambix Publishers

Obakhedo, N.O (2011). Curbing electoral violence in Nigeria: The imperative of political education. International multidisciplinary journal, 5(5)22: pp 99-110

Obioha, E.E (2016). Role of the military in democratic transition and succession in Nigeria. International journal of social science and humanity studies, 8(1): pp 251-268

Odoziobodo, S. I. (2015). INEC and the conduct of elections in Nigeria: An appraisal of the 2007 general elections. European Scientific Journal, 2 (31), 168 - 188.

Odusote, A (2014). Nigeria democracy and electoral process since amalgamation: Lesson from a turbulent past. IOSR journal of humanities and social science;19(10)6; pp 25-37

Ojukwu, U. G ., Mazi, M.C.C and Maduekwe, U.C (2019). Election and democratic consolidation: A study of 2019 general elections in Nigeria. Direct research journal of social sciences and educational 
studies, 6(4); pp 53-64

Okolo, V. O., Ugonna, I. H., Nebo, G. N. \& Obikeze, C. O. (2017). Effects of the social media in the marketing of political candidates in Nigeria. British Journal of Marketing Studies, 5(6), 15-32

Okoro, N. \& Santas, T. (2017). An appraisal of the utilization of social media for political communication in the 2011 Nigerian presidential election. African Research Review, 11(1), 115-135.

Olakunle, $\mathbf{O}$ and Modupe, A (2015). An overview of the 2015 general election in Nigeria. Arabian journal of business and management review (Oman chapter), 5(5): pp 13-20

Olatunji, I (2019). The impact of social media on the 2019 Nigeria presidential election: A CMC connect case study. Retrieved $1^{\text {st }}$ August, 2019. http://www.news-afpra.org/2019/03/11/the-impact-of-socialmedia-on-the-2019-Nigerian-presidential-election/

Olorode, S. O. (2014). A comparative analysis of the use of social media by People Democratic Party and All Progressive Congress" during the 2011 general election in Nigeria. M.Sc Thesis, the Centre for Communication, Media and Society, University of Kwazulu-Natal, Howard College.

Opeibe, T (2019). The Twittersphere on political engagement space: A study of social media usage in election campaigns in Nigeria. Digital studies/Le champ numerique 9(1):6, 1-32

Orji, N (2015). The 2015 Nigerian General election. African spectrum, 50 (2); pp 73-85

Oseni, A.L (2015). How social media revolutionized election in Nigeria. Retrieved $27^{\text {th }}$ of July, 2019. http://benue.com.ng/how-social-media-revolutionized-nigerian-election/

Osinakachukwu, N.P and Jawan, J. A (2011). The electoral process and democratic consolidation in Nigeria. Journal of politics and law, 4(2),128-138

Owen, D (2017). New media and political campaign. Oxford University press

Oyenuga, A.S (2015). Social media participation and pollution of the 2015 general election in Nigeria. Retrieved $27^{\text {th }}$ of July, 2019. http://www.inecnigeria.org/wp-content/uploads/2015/07/conference

PLAC (2012). Social media and the 2011 elections in Nigeria. Policy and legal advocacy center

Rautela, S and Singhal, T.K (2017). Leveraging social media for new product development: $A$ review information technology journal, 2012 (91-100)

Rossini, P., Jeff, H., Sikana, T., Feifei, Z and Jennifer, S.G (2018). Social media, opinion polls, and the use of persuasive messages during the 2016 US election primaries. Social media society; 1-11

Rupak, R., Greg, R., Jei, Y and Ben, J (2014). Technology acceptance model (TAM) and social media usage: an empirical study on Facebook. Journal of enterprise information management, 27(1): 6-30

Schafer, M.T (2011). Bastard culture! How user participation transform cultural production culture. Amsterdam: Amsterdam University press

Shahjahan, A.T.M and Christy, K.U (2014). Social media research and its effect on our society. International journal of information and communication engineering, 8(6), 2-5

Spurgeon, C (2008). Advertising and new media: New York: Routledge

Stefan, S., Tobias, B and Linh. D (2012). Usage of social media for political communication. PACIS 2012 proceeding, paper 22

Stefan, S and Linh, D. X (2012). Social media and political communication: A social media analytics framework. Social networks anals, 1(2); 22-35

Stier, S, Arnim, B., Haiko, L and Markus, S (2018). Election campaigning on social media: Politician, audience and the mediation of political communication on facebook and Twitter. Political communication, 35:50-74

Sule, B.C (2019). The 2019 Presidential election in Nigeria: An analysis of the voting pattern, issues and impact. Malaysian journal of society and space, 15(2): pp 129-140

Suntai, D.I and Targema, T.S (2015). Social media and democracy in Africa: Assessing the 2015 general election experience in Nigeria. Paper presented at the international conference on democracy, dictatorship and development in Africa. Department of history and international studies. Ibrahim Badamosi Babangida University, Lappi, 2-5 August, 2015

Suntai, D. I. \& Targema, T. S. (2017). New media and democracy in Nigeria: An appraisal of the opportunities and threats in the terrain. Brazilian Journal of African Studies, 2(4), 198-209.

Temitope, O. A. S. \& Ahmad, R. (2017). The role of social media during the 2015 voting process in the Nigerian election. Research Journal of Applied Sciences 12(2), 281-287

Thurston, A (2015). Background of Nigeria's 2015 election. Centre for strategic and international studies

Udoka, U.E (2015). Social media and political effects: A case study of the 2015 Nigeria's presidential election. Institutional journal of social science and humanities research, 3

Villi, M and Matikainem, J (2016). Participation in social media: studying explicit and implicit forms of participation in communicative social network. Media and communication, 4(4), 109-117 
Wojtasik, W (2013). Functions of elections in democratic systems. Political preferences, 4:25-38

Chukwu Solomon Ugochukwu was born in Owerri, Imo State Nigeria, 25 th $^{\text {October } 1981 . ~ T h e ~ a u t h o r ~ o p i n e d ~ i n ~}$ a Bachelor degree in transport management from the Federal University of Technology Owerri Imo State Nigeria in 2010; Masters degree in political science and international relations program from Istanbul Aydin University, Department of Political Science and International Relations, Istanbul, Turkey, 2021. 